\title{
The Translator Takes the Stage: Clair in Crimp's The City
}

Geraldine Brodie

g.brodie@ucl.ac.uk

\begin{abstract}
Martin Crimp is a contemporary experimental playwright who translates and is translated. However, translation is not only the system within which Crimp operates: it also informs the content of his writing. This chapter studies Crimp's fictional translator, Clair, in his play The City (2008), investigating her representation of the practice and phenomenon of translation and querying the boundaries of invention within translational narratives. The nature of theatrical representation imposes specific parameters which render theatre translation a relevant site to examine the literary representation of the translator. The City, with the centrality of the translator Clair, documents the presence of the translator in the text, even where the text, the translator, and the play itself, are literary fabrications. Clair epitomizes the paradoxical creativity and destruction of the translational act; the boundaries between creation/original and derivation/translation are insistently teased and worried. In his deconstruction of the role of the translator, embodied by Clair, Crimp addresses the issues of translation as a creative activity and the nature of the translator's re-enactment of an author's invention.
\end{abstract}

\section{Introduction}

The metanarrative of translation is a significant element for the practice of British playwright Martin Crimp. His works are translated into over twenty languages, and some are performed in translation before their English-language premiere. Crimp (b. 1956) also translates French drama for performance in the English language, and is the author of English 
texts for plays that were originally written in German or Russian. However, translation is not only the system within which Crimp operates: it also informs the content of his writing. Crimp's engagement with translation as a practice and phenomenon is particularly evident in his 2008 play The City. Clair, the translator at the heart of Crimp's play, interrogates the activity and ontology of translation at many levels. Clair demonstrates and discusses the tensions between creation and reproduction in her own work through what is seen and heard on stage, but Crimp also manipulates his construction of Clair's character to query the existentialism of translation and creation. Ultimately, Clair gives up her struggle to populate an imagined (or translated) city with characters who could live independently of her invention. "I was no writer - that much was clear. I'd like to say how sad the discovery of my own emptiness made me, but the truth is I feel as I write this down nothing but relief" (Crimp The City: 63). Clair's admission addresses one of the central themes debated by practising translators and academic translation specialists: is translation a creative activity and what is the nature of the translator's re-enactment of the author's invention?

Superficially, Clair appears content to retreat into the derivative work of translation. However, in the context of this play, The City, and this author, Martin Crimp, nothing can be taken at face value. Clair is herself a staged representation, or derivation, of a translator. Her creator, Crimp, is a writer and translator. The play deconstructs the process of translation as invention, both in the person of Clair and in the multiple narratives of text and performance. This chapter explores the presence of the author in translation through an analysis of Clair, her translation practice, and the play in which she herself is invented. Martin Middeke discusses "the openness of [Crimp's] aesthetics and the perceptual multistability it provokes" (99); I argue that Clair's inventor, Martin Crimp, authorizes translation as much in his authorial and textual multistability as in his foregrounding of translation as a concept and an activity. 
The portrayal of multilingualism and translation on stage is not new: William Shakespeare includes a short untranslated scene in French between Katherine, princess of France, and her gentlewoman, Alice, in the second act of Henry V. Later, towards the end of the play, Shakespeare has some fun with translation when Alice translates badly as Henry woos Katherine to be his Queen. Both of these scenes have comic intent. However, plays in English that focus on the translation process or explore its cultural significance are rare. María Irene Fornés, the Cuban-American playwright and director, depicts the 1891 translation into English and staging of Henrik Ibsen's Hedda Gabler in The Summer in Gossensass, dealing with a wide range of issues arising in theatre translation, such as knowledge of the source language, tone of the translation, copyright, casting, character analysis, interpretation, secrecy in production, interpretation of the original play, interpretation through translation, rehearsal processes, and speakability (Fornes). Irish playwright Brian Friel's Translations explores hegemonic interlingual practices in an examination of the British colonial naming operation in eighteenth-century Ireland. These plays foregrounding translation are composed by authors who engage with the process of translation, but they display more than an awareness of the potentiality of translation: translation itself plays a central role. Similarly, the fictionalization of the translation process is seen clearly in Crimp's Clair - her practices and her persona. The City maps out the increasing presence of the translator in the text. Is it possible to view Clair as an avatar for Crimp? Clair's presence in her own text is evident, but to what extent is Crimp also present? This chapter explores the complex relationship between translation and authorship and its staged representation in the multistability of Crimp's translator, Clair.

\section{Theatre translation and performance}

What is particular to theatre translation that rewards an examination of translation processes relating to the literary representation of the translator? Theatre translation is a form 
of literary translation, in that it deals with the transference of a piece of creative work from one language into another. The nature of theatrical representation, however, imposes specific parameters which render theatre translation an applied process. Within the phenomenon of performance, a wide variety of users of a translated play is implicit; the majority of such users - the audience - will not actually read the translated text and will only receive a proportion of the translation - the dialogue. Actors, who transmit the translated text, relay the translation adding another layer of interpretation, consisting of their own reading alongside their non-verbal conveyance of its content. Such actors are among the agents, also including producers, directors, designers, musicians, technicians and other theatre practitioners, who use the translated text (including stage directions and other didascalia) as a tool for the fulfilment of their occupation. Theatre translation is thus differentiated from literary drama translation; this dichotomy examined in detail by translation theorists from Jirí Levý, who identifies "the principle of selective accuracy" when translating for performance (162), to Manuela Perteghella, who argues that adaptation for the stage is "a specific translational practice" (52). Sirkku Aaltonen addresses the implication for translation of the divergences and commonalities within drama and theatre systems, finding that texts "may belong to both or only one of the systems, and they can move in and out of them as well as from one into the other" (33). However, the effect of "page to stage" is as much a feature of theatre and performance studies as of translation studies. Academic fields of investigation into the dramatic staging of textual elements include the development of extended notions of dramaturgy as a "dynamic and fluid conception" of the composition and analysis of theatrical texts (Turner and Behrndt 4), and mise en scène, the "visible part of theatre" that "sets literature into play" (Pavis xv). Furthermore, the discipline of performance studies explores "non-theatrical cultural practices that [share] performance characteristics with theatre" 
(Allain and Harvie 8). Such approaches inform the study of theatre translation in their investigation of textual and cultural interpretations for performance.

Susan Bassnett initiated a debate on the significance of "performability" in translating for the theatre. Almost 30 years later, theatre translation theoreticians continue to grapple with this concept; Silvia Bigliazzi, Peter Kofler and Paula Ambrosi, for example, arguing that a denial of the gestic subtext "only reduces drama to a literary text deprived of performative thrust and translational relevance in the context of theatre" (8). Whether or not performability is translatable, the fact of performance prompts a specialized range of approaches to the translation of texts for the theatre, not least a form of co-authorship or more extended collaboration between a translator and other theatre practitioners to produce the text that is performed on stage. The resulting involvement of non-linguist specialists in the translation process is controversial for theorists and practitioners in translation and theatre alike, and has generated an ongoing examination of the terminology used to describe translations in the theatre, testing the boundaries of translation and adaptation. The variety of terms employed to describe a performed text that has derived from a source text in another language is regularly increasing, and, as I have discussed elsewhere, there is "no consensus on the definition or application of these terms" ("Schiller's Don Carlos in a Version by Mike Poulton, Directed by Michael Grandage: The Multiple Names and Voices of Translation" 123). Contrary to initial expectations, a "translation" may have been written by a target language playwright based on a "literal translation" created by a language specialist; on the other hand, a "version" may have been prepared by an expert linguist. Theatre translation offers a significant opportunity to study the relationship between literature and translation precisely because it demonstrates this range of processes and terminologies, revealing the connections, but also the disconnections, that allow us to examine the ontological function of translation. Furthermore, Martin Crimp's theatrical writing, as I shall discuss, displays a 
variety of these translational processes and terminologies. Crimp's personal engagement with the translation process in its various forms is the source for his theatrical examination of translation in his play The City. Through his translator, Clair, we can deconstruct the tensions between translation and creativity.

Performance is key to Crimp's writing and the translation of his work, and is therefore central to the discussion in this chapter. However, the chapter does not discuss in any detail actual performances of this play. The City received its premiere(s) in 2008, opening firstly in German translation by Marius von Mayenburg at the Schaubühne theatre in Berlin on 21 March, and then one month later in English, on 24 April, at the Royal Court Theatre, London. Even these two, almost simultaneous, iterations of the play foreground the variably interpretive nature of translation. The German production was directed by Thomas Ostermeier, and presented in a double bill with Der Schnitt (The Cut) by the British playwright Mark Ravenhill, thus highlighting new British writing for the theatre. In London, on the other hand, Katie Mitchell directed a reconceived production, in which not only the language of the text, but also the design of the production, was presented without reference to the German production (to which no allusion is made in the playtext that doubles as a programme). Set design, lighting, sound, costumes all combined to offer a first-hand representation of the play by the English Stage Company, whose aim was declared by its first director George Devine on its inception in 1956 “not to be a producer's theatre, nor an actor's theatre [but] a writer's theatre" (Little and McLaughlin). The context of the English-language production is thus focused towards the writerly identity of Crimp rather than his representational quality as a British playwright.

Since these synchronous stagings, further productions of The City have been performed in English, including in Melbourne, Australia (Red Stitch, 2010) and Los Angeles, U.S.A. (Son of Semele, 2012). The play has also been performed in translation further to the 
German production, including Catalan (La Ciutat, Sala Beckett, Barcelona, 2011, translated and directed by Victor Muñoz i Calafell), French (La Ville, Rideau de Bruxelles, 2015, translated by Philippe Djian), and Spanish (La Ciudad, Festival Internacional de Dramaturgia Europa + América 2014, Buenos Aires, translated by Constanza Brieba). Critical analyses of specific productions include discussions by Vicky Angelaki (27-29); Mireia Aragay, Clara Escoda and Enric Monforte (386-89); Aleks Sierz (229-30); and Liz Tomlin (376-77). This chapter, however, reads Crimp's play as text and performance, given his instinct to protect his creations; as he explains, "My plan is to go into a rehearsal room with a non-negotiable document" (Crimp "Attempts on His Life - Martin Crimp - Playwright, Translator, Translated" 13). Crimp writes performability into his dramatic compositions, including the performative act of translation.

\section{Martin Crimp, translator}

Martin Crimp is principally known as the author of contemporary experimental writing for British theatre, and has been described as "one of the most versatile, creative and aesthetically prolific and challenging playwrights of our time” (M. Middeke 82). Crimp's position in the English-speaking dramatic cultural field is demonstrated, along with other indicators, by the extent of critical literature devoted to his work. Book-length examinations of his compositions have been published by Aleks Sierz (2013), Vicky Angelaki (2012) and Clara Escoda Augustí (2013), and Crimp is included in volumes on contemporary British playwrights such as the Methuen Drama Guide to Contemporary British Playwrights (M. Middeke, Schnierer, Peter Paul, Sierz, Aleks) and Fifty Modern and Contemporary Dramatists (Gale). Additionally, reference works such as the Oxford Companion to English Literature and the Oxford Companion to Theatre and Performance include entries on Crimp. Dan Rebellato's record in the latter describes Crimp as an "English playwright”, although concludes with the information that "Crimp has also been acclaimed for translations of plays 
from French" (Kennedy). In fact, the number of Crimp's translations and adaptations is significant in comparison with his original work. Aleks Sierz's second edition of The Theatre of Martin Crimp lists fourteen published play editions (eight of these playtexts are reproduced in collections) and fifteen "translations" (two of which are duplicates). Three of these "translations" have German source texts (Bertolt Brecht's The Jewish Wife, Ferdinand Bruckner's Pains of Youth and Botho Strauss's Big and Small) and a fourth is from the Russian play The Seagull by Anton Chekhov (274-75). Crimp thus displays a willingness to work from languages other than French, in which case he relies on an intermediate "literal" translation, as discussed above.

Should Crimp's English rewordings of German and Russian plays be labelled “translations”? Vicky Angelaki’s 2012 appendix to The Plays of Martin Crimp, detailing “original stagings for plays, adaptations, translations and versions by Martin Crimp", lists all of Crimp's thirty-six theatrical writings at the date of publication (187-99). Angelaki, however, does not attempt to allocate her specified categories to the individual works, an implicit recognition, perhaps, of the porous boundaries identified by Lorna Hardwick "between theoretical models for analysing 'translations' and 'versions"” (195). Furthermore, Angelaki places selected adaptive writings by Crimp, which she classifies as "radical adaptations”, within “Crimp's playwriting canon” . These include The Misanthrope, a direct translation from French, and Cruel and Tender, Crimp's rendering of Sophocles' Trachiniae from Ancient Greek, an indirect translation. Crimp has categorized Cruel and Tender as "a new play based on a pre-existing text" (Laera 216), suggesting that it is the purpose of the rewriting rather than the method of translation or degree of linguistic expertise that governs the typology of the resulting text. Rather than attempting to identify the translations among Crimp's theatrical writing, it may be more fruitful to consider Crimp's activity as a translator, 
and how such activity informs his output - intralingual, interlingual and the intersemiotic in its broadest sense of transposing thoughts into text, and text into action.

Examining Crimp as a translator through the medium of his varied writings permits a study of translational features within the plays of his own authorship. Attempts on Her Life, a seventeen-scenario play simultaneously developing and deconstructing the many existential facets of an absent character, Anne/Annie/Anya, has been described by Rachel Clements as a work of 'rememberers, commentators and ventriloquists' (356). These terms are recognized metaphors of translation in its intertextuality, revisions and reproductions. Crimp's play also explicitly utilizes translation in Scenarios 7 and 16, indicating in his stage directions that the production should incorporate consecutive interpretation of the lines spoken (Crimp "Attempts on Her Life"). In both scenarios, however, translation serves to destabilize the onstage action and alienate the audience. The delayed action of translating into English from "an African or Eastern European language" in Scenario 7 magnifies the force of uncomfortable imagery, for example in the phrase "No man ever rapes and kills a woman in the Anny [a new model of a car in this iteration] before tipping her body out at a red light along with the contents of the ashtray" (Crimp "Attempts on Her Life" 234-38). Scenario 16 ends in a cacophony of three languages spoken simultaneously, with translation contributing to the violent menace of the scenario in a grotesque pastiche of neutral mediation.

Crimp's approach to translation in his writing is in tune with his 'dramaturgy of collapse and testimony' (Escoda Augusti 320). If dramaturgy is a form of translation, and vice versa, it is no surprise that Crimp's voice speaks recognizably in all his theatrical writings, be they originals, adaptations, translations or any other classificatory terminology. Crimp's idiolect can be traced through a range of his outputs to demonstrate his ownership of the written text (Brodie "The Sweetheart Factor: Tracing Translation in Martin Crimp's Writing for Theatre"). His engagement with translation, and the nature of his translational 
activity, can therefore be gauged as much from his treatment of translation as a topic for investigation as from a study of his translated texts. His play The City, with the centrality of the translator Clair, documents the presence of the translator in the text, even where the text, the translator, and the play itself, are literary fabrications.

\section{Clair, the translator}

This chapter may by now have given the impression that Martin Crimp's The City is principally a play about translation. Translation, however, is only one theme among "many dizzyingly different strands", identified by Angelaki as a "focus on the side-effects of capitalism", an "exploration of the art-in-life concept", an "engagement with current affairs", a return to "the couple as nucleus for activity", a "strong dosage of social context", and "even [...] a metaphor for [the translation] process and the translator's role" (24-26). Angelaki reports that the reaction of the critics at the London opening "reflected the interpretive puzzle", but there was a general agreement that "the play resonates strongly by means of Crimp's aptitude for depicting the scale of the impact of modern capitalism" (26).

The action of the play unfolds around a couple, Clair and Chris, their neighbour, Jenny, and their two small unnamed children, only one of whom is represented on stage. The interweaving narratives, conveyed by means of non-sequential and elliptical dialogue between the characters, reveal that Clair has met a writer named Mohamed, who has been subjected to torture. Mohamed gives Clair a blank diary that was intended for his daughter. Clair is a translator, possibly translating Mohamed's work, and attends a translation conference in Lisbon at his invitation. Chris has been working in a large organisation in an unspecified professional capacity, but discovers that he has lost his employment when his security pass ceases to operate. He eventually takes a new job behind the meat counter at a branch of a supermarket chain. Jenny works unsocial hours as a nurse, and her husband is a 
military doctor serving overseas. Jenny complains about the noise of the children playing while she tries to sleep. She insinuates that the children are fighting unsupervised in their playroom. Later, Jenny returns, bringing a knife as a present. The nameless Girl tells her father that her mother is hiding a diary. In the final Act, bringing all four characters on stage together for the first time, Clair gives the diary to Chris, who reads aloud what Clair has been writing: how she invented a city with characters, but was unable to make them "come alive" (Crimp The City 62). As Christopher reads, it appears that not only Mohamed but all of the characters on stage have been invented by Clair, including herself. The play ends with the Girl practising a piece on the piano, and playing a few notes over and over as she is unable to get past the fourth bar.

The characteristic Crimpian multiplicity of layers of meaning and content in The City has generated significant comment and critical review; notwithstanding this range of interpretations, the translator Clare forms the centre around which the other characters and the action of the play revolve. An investigation of her character therefore provides an opportunity to scrutinize practical and theoretical approaches to translation as Crimp presents them in his play. Crimp, however, also provides two peritextual indications of his predilection for the examination of translation. The first is a quotation from Fernando Pessoa on the opening page of the published text: "Everything we do, in art and life, is the imperfect copy of what we intended" (Crimp The City: 5). The second reference to translation does not appear in the English peritext, but can be found in the published French translation by Philippe Djian, set out below a French translation of the Pessoa extract. This second citation constitutes a more overt allusion to translation, recognizing the agency of the translator and coupling translation with writing. "Les questions du traducteur trouvèrent une réponse rapide" ["the translator's questions met with a speedy response" - my translation] is a quotation from Peter Handke's Nachmittag eines Schriftstellers [The Afternoon of a Writer] 
(Crimp La Ville: 9). These two passages also preface the German translation (Crimp Die Stadt), suggesting that Crimp was instrumental in their inclusion. What light do these allusions shed on Crimp's approach to translation and its fictional embodiment in Clair? Clair's onstage translation practice creates echoes that ripple through the play and into the study of translation as a discipline.

The concept of the imperfect copy is central to the portrayal of translation in The City. Clair's opening narrative, in which she recounts her first meeting with the writer Mohamed, describes a little girl in pink jeans being led away by a woman with a nurse's uniform under her coat, and introduces the diary given to Clair by Mohamed. The authenticity of this history is supported by the onstage diary Clair shows to Chris; the book may or may not be removed from its plain paper bag for this evidence - the stage directions are silent on this matter - but the trope of layering and reflexivity is thus established at an early point in the play. Only in Act Two does it become clear that Clair has a professional interest in translation, the scene opening to show her working at a computer while referring to "a book or manuscript", the antithesis of "writing something of [her] own". The reiterative quality of Clair's work is emphasis by the double repetition of "bored with it" (Crimp The City: 16). But if translation is a derivative activity of transference, the copy can also come to life, as becomes apparent when a third character is led onto the stage by Chris, "a woman, Jenny, who is wearing a nurse's uniform under her coat" (Crimp The City: 17). Like the diary, Jenny is an embodiment of a feature of Clair's initial story, and, also like the diary, this evidence of reality is witnessed by a third party. Chris's corroboration is the performative act that transforms the imitative copy into a (staged) independent being.

Clair is thus presented as the derivative inventor of the other characters in the play, but she requires a facilitator, Chris, to complete the creation. Copies proliferate during the course of the play: Jenny describes a pulverized city, which is mirrored in Clair's destroyed 
city of the diary; the Girl, who we assume to be the daughter of Chris and Clair, wears an “exact copy” of Jenny's nurse's uniform on her first entrance (Crimp The City 42); and then in the final scene both she and Jenny are dressed "exactly alike" in the pink jeans of Clair's initial narrative (Crimp The City 63). In each case, these copies are neither identical (although described as "exact", the clothing must vary in size), nor is it clear which version is the “original". Liz Tomlin considers that Crimp's intention is to suggest "the underlying indeterminacy of the world he is authoring" (376). The character list and stage directions, Crimp's direct intervention in the playtext, support this authorial indeterminacy in their blankness on time and place. However, Clair, the translator, is also the author of this indeterminate world, making a further link between creation and translation.

The dialogue between an author and his characters and the consequent paradoxical authorization and destabilization of the creating voice is an established dramatic trope. Sharon Wood views Luigi Pirandello's 1921 play Six Characters in Search of an Author as a work in which "theatre becomes translation bodied forth by the actors, the director and the audience, $[\ldots]$ for each Character, performance is the path to signification, to having their interpretation hailed as dominant truth" (143). Pirandello's director loses control of his characters, as they subvert and take over the performance, questioning their creator while simultaneously corroborating the knowingness of the author who has ultimately scripted the play. Like Pirandello’s “Director”, Clair gives up on her characters. Clair claims that her inventions only "lived a little" (Crimp The City: 62), but in performance the audience has seen these characters come alive and question their creator. Performance bestows existence and meaning on Clair's characters, these imperfect copies of Clair's invention.

Is it defensible to conflate Clair with her own creator, Martin Crimp, in an examination of Crimp's approaches to translation? Crimp describes creating himself as a translator: "I started to read and reread and invented myself as a translator" (Aragay and 
Zozaya: 63). As Clair, Crimp searches for the creation of meaning in the practice of translation, only finding frustration and imperfection. Crimp and Clair dissect the parallels between translation and creation, ultimately falling back on invention to justify their activity. The self-reflexivity of translation as metaphor and practice presents Crimp and Clair as inventions, but if Clair is the invention of Crimp, is it not possible that Crimp is also Clair's invention? Again, we see the translator authorized by means of, rather than in spite of, the indeterminacies of her (or his) activity.

If the trope of "imperfect copy" deconstructs the output of the translator's activity, Crimp's second quotation, only seen in translations of The City and not the original, investigates the input. The quotation "the translator's questions met with a speedy response" highlights the agency of the translator, the poser of questions. The identity of the responder to these queries is indeterminate, as is the resolution of the questions. They are quickly despatched, but is the response constructive or dismissive? The translator is again placed at the centre of the field of activity, rather than the author of the source text, and it is significant that this quotation appears in circumstances where Crimp's authorship has been mediated by another translator. The reference suggests the recognition that the text has been handed over for possession by the translator, in the same way that Crimp takes a form of ownership of the texts that he translates.

Philippe Djian and Marius von Mayenburg both translate directly into their mother tongues from English, and are also particularly well-qualified to translate Crimp's work. Djian is an award-winning playwright and novelist. Several of his novels have been adapted into screenplays, including 37,2 ${ }^{\circ}$ le Matin (1985), which under the English title of Betty Blue was nominated for an Academy Award in 1987. Djian lists seven translated plays on his website (Djian): five works by Martin Crimp, including The City and The Country, and two plays by Harold Pinter, including a retranslation of The Homecoming for the 2012 production 
at l'Odéon-Théâtre de l'Europe directed by Luc Bondy (Gallimard). Djian, might therefore be considered to hold a similarly esteemed status in the French literary system as is accorded to Crimp in the British theatrical system. Crimp himself places Djian in a similar category to his own with regard to translation: "an amateur, in the true sense of somebody who is doing something for the love of it" (Crimp "Attempts on His Life - Martin Crimp - Playwright, Translator, Translated" 2).

Crimp's usual translator into German is Ulrike Syha, also a German playwright. The City, however, was translated by Marius von Mayenburg. The Goethe Institut's website lists forty-four translations of von Mayenburg's authored plays into twenty-two languages, including Chinese, Hebrew and Japanese (Institut). As a dramaturg and translator for the Schaubühne am Lehniner Platz in Berlin, von Mayenburg has worked closely with the director Thomas Ostermeier (who directed the German production of The City). Although predominantly a translator of Shakespeare into German, von Mayenburg has also translated the work of contemporary playwrights Sarah Kane and Richard Dresser in addition to Crimp's The City. Like Crimp, von Mayenburg engages creatively with the translations of other writers: as a dramaturg he has collaborated on German productions of other works by Sarah Kane and also Eugene O'Neill, and he has translated Henrik Ibsen's John Gabriel Borkman based on the translation into German from Norwegian by Sigurd Ibsen, the playwright's son (Platz). The Royal Court Theatre forges a further link between Crimp and von Mayenburg: this theatre has staged several works by both playwrights, including von Mayenburg's The Ugly One (2007) and The Stone (2009) in proximity to Crimp's The City (2008). Djian and von Mayenburg circulate in very similar fields to that in which Crimp resides, translating alongside the experience of being translated, and writing creatively for performance in a variety of modes. 
Crimp and his translators are thus professional theatre practitioners, writers and translators, notwithstanding Crimp's description of the translator as an "amateur". Clare encapsulates the tension between the amateur's "love" and the professional approach necessary for an effective translator. Clair carries out research, speaking to "her" writer on the phone for hours and networking with other translators at a conference (in Lisbon - an intertextual reference to Pessoa and the "imperfect copy"). Clare is sufficiently expert in her career to present a paper at the conference. And yet she is unable to maintain a professional detachment from her occupation; she is defensive of her work, disliking being watched and criticised by Chris, and she becomes possessive of the source text author - possibly to the extent of involvement in a sentimental relationship. From the beginning of the play, Clare is drawn into the narrative of "her" author Mohamed, unable to maintain the dispassionate status of the intermediary which is so often associated with translation, and which Crimp also undermines in Attempts on Her Life. As The City progresses, Clair is increasingly entangled within her translation; the copies proliferate, the narratives intertwine, and it becomes impossible to distinguish reality from invention. Clair epitomizes the paradoxical creativity and destruction of the translational act.

\section{The City: translation or invention?}

The City is often seen as a companion piece to Crimp's earlier play The Country (2000). Both plays depict the apparently settled lives of conventional middle-class families (mother, father, children, comfortable house, professional employment). Clara Escoda considers that both plays "dramatize the effects of late capitalism on character and intimate relationships" (38). The central focus of both plays is on the relationship of the couple and its potential disintegration in the face of life-changing circumstances: Richard's drug addiction in The Country and Chris's unemployment in The City. These factors are further complicated by the external intervention of a former lover (Rebecca in The Country) or neighbour (Jenny 
in The City). However, these brief summaries fail to convey the implicitly violent undercurrents and insidious personal and societal breakdown that generate severe moral discomfort and disorientation for the characters and the audience. Quite apart from the counterpoint of the titles and the inferred location of the plays, The City, like The Country, "subverts the predictability of linearity through the tension and fragments of its unforeseeable content", in Vicky Angelaki's assessment (30). Even though both plays end with a non-verbal projection of inert continuation and repetition - the phone "continues to ring" in The Country (Crimp "The Country": 366); the Girl “can't get beyond bar 4” in The City (Crimp The City: 64) - The City pursues the theme of instability of its forerunner, its imagery forecasting the structural collapse of society, the characters, and the play itself. This instability also interrogates translation.

The final lines of The Country raise questions around authority, simulation and character, issues of invention which can also be applied to translation. "Am I not a character?", asks Richard or Corinne (the dialogue is not specifically allocated to either of the scene's protagonists and arguably could be spoken alternately by each of them). "Oh yes you're a character - very definitely a character - but quite a different character" comes the reply (Crimp "The Country": 366). The reflexivity of this allusion to the invention of the author, Crimp, and the shifting portrayal of Richard (or Corinne); the reminder to the audience that this is indeed a play - an exercise of the imagination - draws attention to the craft of the composition and the technical skills of the playwright. This foregrounding of artistry is developed in The City simultaneously to undermine and sustain translation.

Act One of The City establishes Clair as an authority on writers: she situates herself among "people who know about writing" (Crimp The City: 10). When in Act Two, it becomes clear from her working practices, and from her husband's intimations of her occupation, that Clair is a translator, the connection is made between writer and translator, 
but also between translation and literary criticism. Clair differentiates between the desk work of translating, which can be "dull", and the opportunities it gives her to meet authors, some of whom are "real characters" (Crimp The City: 16). As I have shown, Clair's life as a translator unfolds during the play, while the object of her translation, the writer Mohamed, is increasingly obscured. Clair recounts a meeting with him and further details of his life and family in Act One, and attends a translation conference which he organises in Act Four, bestowing a concrete existence on this unseen protagonist. Nevertheless, the reflexivity of the term "character", just as this term is employed in The Country, problematizes Mohamed's reality, laying a trail of existential jeopardy for Mohamed and ultimately all the personages, on stage or mentioned, in the play. According to Angelaki, from the story in Clair's diary "it appears that everyone and everything around Clair, including herself and Chris, are figments of her imagination, mere cogs in constructing the wider frame of her life" (27). This interpretation suggests that Clair in some way exists outside the diary. The diary, however, could rather be a metaphor both for the (imagined) city in which the participants live and work and for the act of invention/translation. The diary is not Clair's creation, but a receptacle in which Clair is created, a record of events which can only be read subjectively and at second hand. Furthermore, the diary itself is a real object, one of the few properties stipulated in the stage directions. It is onstage as the play begins, "a flat object in a paper bag" (Crimp The City: 7), and is closed by Christopher, whose reading from the diary forms the denouement of the play, as the last lines are spoken.

The diary thus frames the play, undermines "truth", queries creative writing, and requires a performative act (reading aloud by Christopher) to be interpreted. Ultimately, it fails in all these purposes. Middeke sees correspondences between Derrida and Crimp in their treatment and use of "the iterability of a sign. [...] No context surrounding a sign could ever capture it completely. It is precisely this radical openness that displaces representation, 
meaning and (complete) understanding in Crimp into an ineluctable presence/absence" (99). The diary in The City represents fact and fiction. Intended for Mohamed's daughter, it passes through the hands of Mohamed, Clair, Clair's children and ultimately Christopher, before its contents are transmitted. Like Sirkku Aaltonen's theatre translation time-sharers, each of these agents handle and interpret the diary, leaving their marks to accumulate but never attaining resolution. Translation in The City is thus endowed with the same "ineluctable presence/absence" as Crimp himself; translation informs the content and the composition of the play, the boundaries between creation/original and derivation/translation are insistently teased and worried, but translation itself never appears at the centre of the action or conversation. The translator, however, is central to the play.

\section{Conclusion}

Elisabeth Angel-Perez observes that "The City revolves around the character of a translator who in the end 'authorises' all the characters of the play as she may well have invented them all" (354). Clair invents herself as a character within her translational narrative, blurring the boundaries between creation and derivation, and investing the very imperfection of her copies with originality. Clair's inventor, Martin Crimp, authorizes translation as much in his authorial and textual multistability as in his foregrounding of translation as a concept and an activity, deconstructing the complex nature of translation as a social and literary practice. The City can be read as a treatise on translation and creativity, but also as an examination of the translator's role in the text. By placing Clair in a central position both within her own translated/invented text and within the text he himself has created, Martin Crimp underlines the reflexivity of translation. Clair mourns the ruined city that she has failed to bring to life, but this void, or absence, strengthens her presence as 
creator. The fictional translator reassesses her role in the literary system, and steps out into the spotlight.

\section{Reference List}

Aaltonen, Sirkku. Time-Sharing on Stage: Drama Translation in Theatre and Society. Clevedon: Multilingual Matters, 2000. Print.

Allain, Paul, and Jen Harvie. The Routledge Companion to Theatre and Performance. Abingdon: Routledge, 2006. Print.

Angel-Perez, Elisabeth. "Martin Crimp's Nomadic Voices." Contemporary Theatre Review 24.3 (2014): 353-62. Print.

Angelaki, Vicky. The Plays of Martin Crimp: Making Theatre Strange. Basingstoke: Palgrave Macmillan, 2012. Print.

Aragay, Mireia, Clara Escoda, and Enric Monforte. "Martin Crimp at Sala Beckett, Barcelona." Contemporary Theatre Review 24.3 (2014): 378-89. Print.

Aragay, Mireia, and Pilar Zozaya. "Martin Crimp." British Theatre of the 1990s: Interviews with Directors, Playwrights, Critics and Academics. Eds. Aragay, Mireia, et al. Basingstoke:

Palgrave Macmillan, 2007. 56-76. Print.

Bassnett, Susan. "Ways through the Labyrinth: Strategies and Methods for Translating Theatre Texts." The Manipulation of Literature: Studies in Literary Translation. Ed. Hermans, T. London: Croom Helm, 1985. 87-102. Print.

Bigliazzi, Silvia, Peter Kofler, and Paola Ambrosi. "Introduction." Theatre Translation in Performance. Eds. Bigliazzi, Silvia, Peter Kofler and Paola Ambrosi. Abingdon: Routledge, 2013. 1-26. Print.

Brodie, Geraldine. "Schiller's Don Carlos in a Version by Mike Poulton, Directed by Michael Grandage: The Multiple Names and Voices of Translation." Authorial and Editorial Voices in Translation Volume1: Collaborative Relationships between Authors, Translators, and Performers. Eds. Jansen, Hanne and Anna Wegener. Montréal: Éditions Québécoises de I'CEuvre, 2013. 119-40. Print.

---. "The Sweetheart Factor: Tracing Translation in Martin Crimp's Writing for Theatre." Journal of Adaptation in Film and Performance forthcoming (2016). Print.

Clements, Rachel. "Deconstructive Techniques and Spectral Technologies in Katie Mitchell's Attempts on Her Life." Contemporary Theatre Review 24.3 (2014): 331-41. Print.

Crimp, Martin. "Attempts on Her Life." Plays Two. Ed. Crimp, Martin. London: Faber and Faber, 2005. 197-284. Print.

---. "Attempts on His Life - Martin Crimp - Playwright, Translator, Translated." Journal of Adaptation in Film and Performance (forthcoming) (2016). Print.

---. The City. London: Faber and Faber, 2008. Print.

---. "The Country." Plays Two. Ed. Crimp, Martin. London: Faber and Faber, 2005. 285-366. Print.

---. Die Stadt. Reinbek: Rowohlt Theater Verlag, 2008. Print.

---. La Ville. Paris: L'Arche, 2008. Print.

Djian, Philippe. "Philippe Djian: Traductions." 2015 2015. Web. 8/24/2015 2015.

Escoda Augusti, Clara. Martin Crimp's Theatre: Collapse as Resistance to Late Capitalist Society. Berlin: De Gruyter, 2013. Print. 
Escoda, Clara. "Violence, Testimony and Ethics in Martin Crimp's the Country and the City." Ethical Speculations in Contemporary British Theatre. Eds. Aragay, Mireia and Enric Monforte. Basingstoke: Palgrave Macmillan, 2014. 25-41. Print.

Fornes, Maria Irene. "The Summer in Gossensass." What of the Night?: Selected Plays. Ed. Fornes, Maria Irene. New York: PAJ Publications, 2008. 47-97. Print.

Gale, Maggie B., Deeney, John F., ed. Fifty Modern and Contemporary Dramatists. London: Routledge, 2014. Print.

Gallimard. "Harold Pinter: Le Retour [the Homecoming]." 2012 2012. Web. 8/24/2015 2015.

Hardwick, Lorna. "Negotiating Translation for the Stage." Theorising Performance: Greek Drama, Cultural History and Critical Practice. Eds. Hall, Edith and Stephe Harrop. London: Duckworth, 2010. 192-207. Print.

Institut, Goethe. "Theater in Deutschland - Theaterbibliothek - Marius Von Mayenburg." 2015. Web. 11 November 2015.

Kennedy, Dennis, ed. The Oxford Companion to Theatre and Performance. Oxford: Oxford University Press, 2010. Print.

Laera, Margherita. "Theatre Translation as Collaboration: Aleks Sierz, Martin Crimp, Natalie Abrahami, Colin Teevan, Zoë Svendsen and Michael Walton Discuss Translation for the Stage." Contemporary Theatre Review 21.2 (2011): 213-25. Print.

Levý, Jirí. The Art of Translation. Amsterdam: John Benjamins, 2011. Print.

Little, Ruth, and Emily McLaughlin. The Royal Court Theatre inside Out. London: Oberon Books, 2007. Print.

Middeke, Martin. "Martin Crimp." The Methuen Drama Guide to Contemporary British Playwrights. Eds. Middeke, Martin, Peter Paul Schnierer and Aleks Sierz. London: Methuen Drama, 2011. 82-102. Print.

Middeke, Martin, Schnierer, Peter Paul, Sierz, Aleks, ed. The Methuen Drama Guide to Contemporary British Playwrights. London: Methuen Drama, 2011. Print.

Pavis, Patrice. Contemporary Mise En Scène: Staging Theatre Today. Abingdon: Routledge, 2013. Print.

Perteghella, Manuela. "Adaptation: Bastard Child or Critique? Putting Terminology Centre-Stage." Journal of Romance Studies 8 (2008): 51-65. Print.

Platz, Schaubühne am Lehniner. "Marius Von Mayenburg." 2015. Web. 11 November 2015.

Sierz, Aleks. The Theatre of Martin Crimp. second ed. London: Bloomsbury, 2013. Print.

Tomlin, Liz. "Citational Theory in Practice: A Performance Analysis of Characterisation and Identity in Katie Mitchell's Staging of Martin Crimp's Texts." Contemporary Theatre Review 24.3 (2014): 373-77. Print.

Turner, Cathy, and Synne K. Behrndt. Dramaturgy and Performance. Basingstoke: Palgrave Macmillan, 2008. Print.

Wood, Sharon. "The Pirandellian Mise-En-Scène and the Vanishing Translation." Theatre Translation in Performance. Eds. Bigliazzi, Silvia, Peter Kofler and Paola Ambrosi. Abingdon: Routledge, 2013. 140-49. Print. 